\title{
Analysis of the Spoken English Used by Teachers in Kenyan Primary School Classrooms: Phonological and Grammatical Variations
}

\author{
Martin C. Njoroge* \\ Department of Communication, Languages and Linguistics, Pan Africa Christian University, Nairobi, Kenya \\ *Corresponding author: martin.njoroge@pacuniversity.ac.ke
}

\begin{abstract}
The research reported in this paper identifies and describes phonological and grammatical variations in the English spoken by teachers at Kenyan primary school level, correlates the variations observed with the teachers' amount of education completed in the English language and discusses pedagogical implications of the emergent patterns. First, the results indicate that the teacher's spoken English varies from the British standard variety - the model of correctness at all the education tiers in Kenya - and second, that the amount of education a speaker has completed in the English language significantly influences language variability. The findings imply that if more primary school teachers were to receive further exposure to English grammar and phonology through the continuing education programs available in Kenyan universities, their spoken English would then vary less from the standard English and international mutual intelligibility would be improved.
\end{abstract}

Keywords: English, Phonological and Grammatical Variations, Kenyan primary school

Cite This Article: Martin C. Njoroge, "Analysis of the Spoken English Used by Teachers in Kenyan Primary School Classrooms: Phonological and Grammatical Variations.” American Journal of Educational Research, vol. 5, no. 10 (2017): 1087-1096. doi: 10.12691/education-5-10-10.

\section{Introduction}

In the recent past, a number of teachers in primary schools in Kenya have been able to advance their education to bachelor's level and beyond and many of these teachers have already graduated from what is referred to as 'Continuing education'. Kenyatta University, for example, has been offering this program since 1998 and I have taught several courses in English and Linguistics to some of these students. I have been curious to find out whether the knowledge the teachers acquire through the English courses offered at the university significantly influences language variability; hence, the interest in establishing the relationship between language variations observed in this study with the social variable of the amount of education completed in English.

Further, for five years I have been a national English Language examiner with the Kenya National Examinations Council, and year after year, there are heated arguments on what norm should guide the drafting of the marking schemes. Some examiners argue that the examining body should continue using the British standard variety as stipulated in the syllabus, while others feel that the native speaker model as used in Britain is not what the learners are exposed to, and thus should not be the ideal model. They argue that learners in Kenya are exposed to an educated Kenyan variety of English that their teachers use in the classroom. However, the latter group is reminded that what they refer to as Kenyan
English has not been accepted, described and put together in dictionaries and grammar books and thus cannot be used as the norm when it comes to determining the accuracy of the marking schemes. Such debates provide a rationale for this study, which sought to determine the reality on the ground. Are the learners in the classrooms exposed to native-like norms or does the teachers' English deviate from this ideal norm?

English and Kiswahili are the two key languages in Kenya. ${ }^{1}$ While Kiswahili is a national language, English is an official language and is actually the medium of instruction in Kenyan schools. The model of English used in Kenyan schools, even at the elementary level, is claimed to be the British standard, particularly Received Pronunciation (RP) [1]. RP is the prestigious dialect that is spoken in the southern parts of Britain and it is used in the media and in the education system.

The assumption in Kenya is that at all the school levels, the teachers, who are the learners' main linguistic models, have an excellent command of this yardstick of correctness and appropriateness with regard to pronunciation, grammar and lexis and that such teachers can teach the said variety. This assumption presupposes that teachers in Kenya will use similar linguistic forms to those that a prestigious British standard speaker uses in England despite their regional and socio-cultural differences [2]. But is this indeed the case?

\footnotetext{
${ }^{1}$ Kenya is a highly multilingual society and actually there are over 40 indigenous languages. Nearly everyone in Kenya is bilingual and some are trilingual.
} 
Studies in second language learning note that a teacher's language use will in a great way influence the quality of the learner's language and will have a bearing on the learner's linguistic competence $[3,4]$. This then justifies research that sets out to discover whether the teachers of English in Kenyan primary schools present to their learners forms that are similar to RP's, the model upon which Kenya national English examinations and the English language syllabus are based. If their English varies from the norm, then it is important to discuss the implications the emerging patterns have for pedagogy in Kenya. Determination of the exact model that learners are presented with in the classroom is paramount if achievement of quality education by learners is to be realised. $^{2}$

\section{Literature Review}

\subsection{English in Non-native Contexts}

In some non-native English speaking nations, a great deal of research has been undertaken with a view to describing the linguistic forms of the variety of English spoken by the citizens [5]. In a number of countries, for instance, India and Singapore, there has been an adoption of the localised variety as the language of wider communication. Linguists in such countries have identified and codified a local standard variety of English. Thus, we talk, for example, of Singlish ${ }^{3}$, which, despite the controversy, functions in Singapore as an important language of the media (Lemon, n.d.) [35]. In Nigeria, researchers such as Bamgbose [6] and Bokamba [7] have described what can be referred to as Nigerian English. Grammar books and dictionaries have been written and compiled so that teachers and other speakers of English in Nigeria may have some points of reference for a variety of English that is presently termed Nigerian English [8]. Chick \& Wade [9] also present features that mark what they refer to as Black South African English. To the best of my knowledge, however, little has been done to codify and put together forms that can characterize what is informally referred to as Kenyan English.

Research into some of the non-native varieties such as the one used in Kenya has lagged behind [10,11]. One of the reasons highlighted for this lack of enthusiasm is the myth that the English taught in non-native contexts such as Kenya is the British standard [12]. Another reason that is put forward is the fear that if a variety other than the native-speakers' is accepted as the appropriate model for education, it may degenerate into a very different language that will lack mutual intelligibility with the standard varieties. Third, there is the influence of the prescriptivists who analyse any deviation from the native speakers' varieties as errors [11]. The absence of research

\footnotetext{
2 One of the Millennium Development Goals is the achievement of Universal Primary Education by the year 2015 and issues of norms ought to be addressed for realistic policies to be designed and implemented.

${ }^{3}$ See for example Rani Rubdy's [34] analysis of realities and practice in language in education in Singapore. She notes that Singlish has emerged as the symbol of intraethnic identity and cultural integration in Singapore and that $70 \%$ of Singaporeans accept it as a marker of rapport and solidarity. It has been exploited in literary writings and in the media.
}

that describes English as used by educated speakers of English in Kenya as represented by teachers of English in the study sample is thus timely.

\subsection{The Language Situation in Kenya and the Place of English}

The Republic of Kenya Housing and Population Census [13] reports that $75 \%$ of the population speaks languages belonging to the Bantu family, which include Gikuyu, Kamba, Luhya, and Kisii. Around 20\% speaks NiloSaharan languages such as Dholuo, Maasai and Kalenjin. The rest speaks Cushitic languages, which comprise Somali, Oromo and Rendile. These ethnic languages serve as languages of group identity at the sub-national level.

English is used in a multilingual environment in Kenya. Unlike those who use it as their only code, Kenyans use English as only one of several codes. For example, most Kenyans have a proficient command of their ethnic language, Kiswahili and English while others even speak French, German or other Kenyan indigenous languages. Because of this phenomenon, there is bound to be much code mixing and switching, as well as lexical and phonological influences as these languages interact.

In Kenya, the importance of English increased after independence from Britain in 1963, which ended approximately sixty years of colonization [14]. English plays a significant role in Kenya as the language of education, administration, commerce and modernization [15]. Kanyoro [16] adds that English in Kenya is associated with socio-economic prestige. It is exclusively a high status language associated with white-collar jobs and major responsibilities within the government and the private sector. Mastery of English is a ladder to success and therefore, there is motivation for learning the language. As Muthiani and Muchiri [17] observe, proficiency in English is often the yardstick by which young Kenyans are judged. English is indeed used as a measure of a person's educational achievement and success in life [10].

Schmied [18] observes that the British standard is still regarded as the standard norm among Kenyans. He finds that linguistic variations in English, as used in places such as Kenya, however, have covert prestige. He says that the vernacular (non-standard) forms of English seem to function as a symbol of group identity, which is used to signal national solidarity even by those who have, through study and travel, clear links with Standard English speakers, but who do not necessarily want to be associated with them in the national context.

\subsection{Kenya’s Language-in-education Policy}

The language-in-education policy in Kenya is spelled out in the Totally Integrated Quality Education and Training report, a guideline for the education system in Kenya [19]. In the rural set-ups, the medium of instruction in the lower primary is the learner's mother tongue or the dominant language within the school's catchment area. However, within Nairobi and other urban centres where the population is made up of people from different ethnic groups, Kiswahili is the medium of instruction. In upper primary English is to be used as the medium of instruction 
throughout the country. To enhance concept formation and articulation in linguistic communication, children should continue to be taught in their mother tongue or the dominant language of the school environment until primary 3. During this period, English and Kiswahili, the official and national languages respectively, should be taught vigorously as subjects. In upper primary (primary 4 to 8), when the child has already mastered English and Kiswahili, English should then be introduced as the medium of instruction. The revised English syllabus used in Kenyan schools [12] states that the reference point to be used in teaching English is the British Standard English, specifically Received Pronunciation. It was the objective of this study to determine if teachers of English in Kenya schools used this standard in their teaching.

\subsection{RP's Phonetics and Phonology}

RP is the prescribed model in Kenya's formal instructions. The manuals on RP's phonetics and phonology by Jones [20] and Roach [21] include clear descriptions of the phonemes and their articulation in RP. Briefly, RP phonemes are identified by means of the discovery technique of minimal pairs. Roach [21] identifies 20 vowel phonemes (12 monophthongs and 8 diphthongs) and 24 consonants to make 44 phonemes in the phonemic inventory of RP. These $\mathrm{RP}$ phonemes are indicated by means of the appropriate phonemic symbols from the list of the International Phonetic Alphabet (IPA) [21]. The consonant phoneme /b/, for example, is classified as a voiced bilabial plosive while the phoneme /f/ is a voiceless labio-dental fricative. The phoneme /b/, for example, occurs initially in a word as in /beit/, medially as in /teibl/ and finally as in /slæb/. The teachers and learners in Kenya are expected to adhere to RP's phonetics and phonology.

\section{Research Problem and Scope}

Much of the available research into the spoken English language in Kenya has concentrated on code switching [22], analysis of errors in learners' language at different educational levels [23], and issues in English language teaching methodologies [24]. However, hardly any of these approaches consider the interaction between English language and the indigenous languages, or how social variables such as gender and education interplay with English to reflect the socio-cultural changes that English has been made to undergo in Kenya. Likewise, Wardhaugh [25] points out that spoken forms of a language are not uniform entities but vary according to the area people come from, their social class, their gender and age, ethnicity, their level of education, among other social variables. Thus, the English language as it is used in, for instance, Kenya, is bound to show variation from the variety spoken in Britain due to differences in sociolinguistic contexts.

The research focused on analysing spoken English as used by graduate and non-graduate teachers in Kenyan primary schools to identify variations. These are the features observed in the spoken English used by teachers in Kenyan primary schools that make it unique and distinct from the British standard variety, the norm of correctness in Kenya. The length of formal instruction that a speaker had received in English represented the education variable in the study. Focusing on other social factors such as ethnicity, gender and age, despite their importance, would have made the scope too wide.

\subsection{Rationale for Choice of Subjects}

The rationale of the choice of teachers of English at the primary school level rests on the premise that they are the ones charged with the responsibility of imparting to the learners the four language skills, namely reading, writing, speaking and listening [26]. In the Kenyan context, just like in many second and foreign language-learning contexts, learners get exposed to English through formal instruction and the majority get to hear an English word for the first time when they get to school. The teacher in such a case is the most important source of input and as Ellis [4] observes, the learners' linguistic competence is greatly influenced by the characteristics of the input that the learners receive from their teacher. Ellis further states that some errors in the learner's language will derive from the way in which the teachers use the target language [27]. These factors justify a study that examines spoken English used by teachers in the classroom.

\section{Research Objectives}

The study aimed to:

a) Identify phonological and grammatical characteristics of the variety of English as used by teachers in Kenyan primary schools.

b) Describe phonological and grammatical differences between the variety of English used by these teachers and the British standard variety.

c) Establish, by statistical means, the significance of the differences in linguistic usage between two groups of teachers that vary in the amount of education completed in the English language.

d) Outline pedagogic implications of the emergent sociolinguistic patterns.

\section{Methodology}

\subsection{Research Design}

The study was designed to investigate the relationship between one binary predictor variable (years of instruction in English) and multiple continuously scaled linguistic dependent variables. According to Schneider [28], research within the Language Variation Paradigm falls within quantitative research design. Essentially, the variationist paradigm builds upon quantitative methodology, aiming to establish relationships between social factors and linguistic variables. Nevertheless, qualitative analyses adopted in the study help to illustrate the nature of linguistic variations (see nature of variation section below). 


\subsection{Sites, Population and Sample Size}

To achieve the aims of the study, data were collected from teachers of English in the rural areas of Kenya's Bomet, Siaya and Thika districts and from Nairobi area, an urban setting. Judgemental sampling method and the social network approach [29] guided the researcher in choosing the required study sample. The underlying principle of judgemental sampling method entails identifying in advance the target variables. This then presupposes the type of respondents to be studied. Milroy and Gordon [29] note that if the research questions highlight relationships between variables, or comparisons between groups, then judgement sampling is appropriate since it makes sense to select the sample in such a way that there is maximum chance for any relationship to be observed. The social network approach, on the other hand, looks at an individual in a speech community as having specified networks of relationships with other individuals whom he or she depends on and who in turn depend on him or her. Thus as a researcher, I was able to enter the field to collect the language data as a friend of a friend, and this aspect helped to reduce the Observer's paradox.

The study's target population were teachers of English in Kenyan upper primary schools. The research sample was made up of 48 primary school teachers. According to the distribution principle, a larger sample would not necessarily have given varied data but more examples of the same [30]. In the same vein, Milroy \& Gordon [29] point out that variation studies do not require the statistical analysis of hundreds of speakers' records as variations can emerge even from samples as small as twenty-five speakers. Considering such views, the researcher concluded that a 48-member sample would be sufficient to enable an exhaustive study of linguistic variations in the spoken English as used by teachers in the targeted areas.

\subsection{Predictor Variable: Number of Years of Instruction in the English Language}

Teachers' educational level measured by the number of years of instruction in the English language was the independent variable in the study. Education in this study is used to represent the level of exposure to English that the teachers have had; hence, there was need to take care of this during sampling procedure. Twenty-four of these teachers (graduates) had attained a bachelor's degree in English language while twenty-four had only been awarded the primary teaching certificate (non-graduates). The former had at least sixteen years of formal instruction in the English language while the latter had twelve.

\subsection{Linguistic Dependent Variables}

The study adopts Wardhaugh's [25] definition of a linguistic variable as a linguistic item, which has identifiable variants. Variation in language is an extremely complex phenomenon, and it would be quite unrealistic to attempt to analyse all its aspects. In this connection, the study limited itself to the analysis of the following linguistic variables:

a) Phonological: plosives (p, b, t, d, k, g ) and approximants $(\mathrm{l}, \mathrm{r})$. b) Grammatical: use of the article (omission, redundant use and wrong choice); use of the preposition (omission, redundant use and wrong choice); pronoun copying and subject-verb agreement.

A little needs to be said about the variable of pronoun copying as used in the study. It refers to the occurrence of a noun phrase followed immediately by a pronoun with the same referent within a sentence or utterance. Unlike in English, this pattern is grammatical in most African languages [18].

\subsection{Fieldwork and Data Collection Procedures}

Classroom interactions during English lessons were tape-recorded three times to obtain the language data. Though the interactions during the first visit were taperecorded, the language data were not used because the visit was only meant to take care of Observer's paradox. Since the aim in the research was to find variations in the spoken English of teachers and to capture these as naturally as possible, an initial visit helped to establish a more natural and relaxed environment thus lowering teachers' inhibitions. The first visit, therefore, helped to reduce teachers' anxiety and they had relaxed by the time I made the second one. Thus, only the one-hour language data tape-recorded during the second and third visits were coded and analyzed. After all the three visits, I played back the recording for the respondent who would then listen and point out whether there were some areas he/she did not like, so that they could be deleted. Happily, they never asked me to get rid of any section.

\subsection{Methods for Quantifying the Linguistic Dependent Variables and Data Analysis}

The teachers' spoken language data was first transcribed, and then analyzed to identify the variants of each. Variation in the articulation of consonants was identified through the approach used by Roach [21] and Wells [31]. Quirk, Greenbaum, Leech \& Svartvik's [32] approach was used for the grammatical variation. I also made use of Oxford Advanced Dictionary in determining a correct description of the specified variation. The second opinion of $\mathrm{Mr}$. Girling, a native RP speaker, was crucial in crosschecking the accuracy of the linguistic variations identified. After this, the total tokens for each variant were determined by counting frequency of occurrence of the specific variant in the language data of each teacher, in each of the two teacher-categories, and in the entire language data. This was followed by calculations of the means and standard deviations for each variant, using a computer package, Statistical Package of Social Science (SPSS).

There was need for the linguistic data to be analysed statistically to establish whether there was any correlation between the variation observed and the teachers' level of education. To accomplish this, analysis of variance (ANOVA) was used. The data were thus further analysed to display ANOVA of the linguistic variants that occurred in the teachers' spoken English. ANOVA demonstrated whether the observed differences between two sample means were purely random or whether there were real 
differences between the means. In the application of the ANOVA, the researcher wished to see whether variability in the dependent linguistic variables in graduate and non-graduate was statistically significant at $\mathrm{p}<0.05$, so that it could be concluded that the means were different. The results were then presented in tables showing frequency of occurrence, means and standard deviations and levels of statistical significance.

\section{Results}

\subsection{Nature of Variations}

Holding all factors constant (gender, ethnicity, rural/urban dichotomy and other social factors), data analyses revealed that the English spoken by teachers in primary schools in Kenya varied significantly from the British standard variety. This was noted mostly in the phonological variations. For example, variations were noted in the use of the labio-dental fricatives [f] and [v]; approximants [r] and [l]; the alveolar fricatives [s] and [z]; the velar plosives [k] and [g] and the inter-dental fricatives $[\theta]$ and $[t]$ among others. Grammatical variations were also noted in the use of the article, preposition, subject verb agreement and pronouns. For example, there was omission of an obligatory article, redundant use of a preposition and lack of agreement between the subject and the verb. The following examples drawn from the teachers' spoken data illustrate the nature of variation. The transcriptions are based on how the teachers pronounced the specific word.

\subsection{Phonological Variation}

\section{(a) Grad. 1}

That word is [lialais]. Class say [lialais]. I want those realize realize

who have not [led] to [li:d]. [meli], please [li:d]. read read Mary read

These are questions [flom] the [stoli] and we cannot be from story

to answer those questions unless we [li:d] again and read

understand it.

\section{(b) Non-grad 5}

We talk of [lili] when something is [veli] small and really very

another [veli] big. A cheetah can [lan] [veli] fast. very run very

The coconut [tli] is [lili] tall. tree really

He was [laða] disappointed. He was not [feli] pleased. rather very

As we had said earlier, adjectives [desklaib] a noun. describe

In a number of instances where the approximant [r] was expected in the RP, the lateral approximant was used as examples in (a) and (b) show. Other words which were supposed to be articulated with the approximant [r] but were produced with a lateral approximant [1] are writing, porridge, very, removing, correct and serious. Consequently, the words very [veri] and correct [kərekt] were articulated as [veli] and [kolekt] in the study data.

In addition, variation was noted in the use of voiced and voiceless labio-dental fricatives as in the following examples.

\section{(c) Grad 4}

If you look at our book page eighty [faif] write for me five at least [faif] sentences using the word [fain] five vine

Another phonological variation observed was in the use of bilabial plosives [p] and [b] as in the following examples.

\section{(d) Non-grad 40}

Once there was a [pig] lion, staying in a forest... big

he tried his [pest] to [prek] the net, [pat] he couldn’t so best break but

the lion struggled. So, he used his teeth

You can see some[pJdi] who is very rich. somebody

The lion was just walking [postfuli] boastfully

\section{(e) Non-grad 46}

Yes when the [pel] rings. Yes a few days ago, bell

you drew and [lepəd] many parts of the [paisikJ]...

Say a [pวtl] to carry milk. labelled bicycle bottle

A person who works who [puilds] a house is called build

a [puilder] person who works in a [laiprari] is builder library

a [laiprarian]. A [prodkasta] works in a newsroom. librarian broadcaster

A [put $\int$ a] works in a [put $\int$ ari]. The cashier works in butcher butchery a [pank].

bank

In example (e), the word bell was articulated with sound [p] thus producing [pel]. Likewise, the word labelled [leibld] was articulated in the study data as [leipJd] instead of [leibld] in RP. Similarly, the words bank [bæyk] and bone [bəun] were articulated as [payk] and [pon] respectively. It is worth noting that this particular variant occurred in word-initial and wordmedial positions.

\section{(f) Grad 22}

When you are introduced to a stranger by a friend, we [usuali] say "It is a [plesa] to meet you." usually pleasure 


\section{(g) Non-grad 24}

You must have learnt this in science. A thermometer is used to [mesa] what? Can You say to [mesa] temperature. measure measure

In examples (f) and (g), the voiceless alveolar fricative [s] was used in the highlighted words, instead of the expected voiced post-alveolar fricative [3] in RP. For instance in (g), the word measure [mezə] was articulated in the study data as [mesa]. The use of variant [s] instead of the voiced post-alveolar fricative seems to be influenced by a mismatch between orthography and pronunciation. In the highlighted words in and (f) and (g), the grapheme $\langle\mathbf{s}\rangle$ is used in orthography but in pronunciation, the voiced post-alveolar fricative [3] is the expected sound.

\subsection{Grammatical Variation}

In this study data, variations were also observed in contexts where there was use of pronoun copying. In cases where a noun phrase subject was expressed, there were a number of cases in which the subject was followed by a pronoun referring back to the subject. Thus, the subject was expressed twice.

\section{(a) Grad 2}

Soi's grandmother she took him to the bus stop because Soi had to leave early in the morning.

The grandmother she feared that Soi would be attacked. It was still very dark.

Think about what happens in a harbour, like Kenya's Kilindini harbour. Somebody? Very good. The containers they were being lifted up.

In the examples in (a), the occurrence of a pronoun immediately after the noun phrases that function as the subject in the sentences can be noted. In so doing, it becomes as though there is occurrence of double subjects within the same sentence, though these two subjects have the same co-referent.
Use of the article displayed variation as illustrated below:

\section{(b) Non-grad 40}

[omis. of indef.art. a] rat is a very small animal and [omis. of indef.art.a] lion is a big animal. So [omis. of def.art. the] lion, no [omis. of def.art. the] rat said...so [omis. of def.art. the] rat ran away... so [omis. of def. art. the] rat lived in hole.

In the examples highlighted in (b), there is the omission of either the definite article the or the indefinite articles a and an. For example, the indefinite article $\mathbf{a}$ is needed to indicate that the noun 'rat' is a count noun and that it is being mentioned for the first time in the discourse. The second time the noun 'rat' is mentioned means that it has a direct anaphoric reference and, therefore, it requires that the definite article the be used to indicate that the two nouns have co-reference relations. However, in the study data, the article was omitted as example (b) shows.

\subsection{Statistical Presentation}

The frequency of occurrence of the linguistic variants was calculated and results presented in tables (see Appendices). In the phonological variation, the use of post-alveolar approximant $[\mathrm{r}]$ where the alveolar approximant [1] was expected had the highest frequency (159) while the use of the voiced bilabial fricative instead of the expected voiced bilabial plosive was the lowest with only 16 occurrences. In the grammatical variation, substitution of preposition had the highest frequency of occurrence (167) while redundant use of the indefinite article an had the lowest (14). Variations in pronoun copying and subject verb agreement also recorded high frequencies.

Descriptive statistics (see Appendices) show that the means for the graduate speakers were generally lower than those of the non-graduates. In addition, the standard deviations across all the linguistic variants indicate that the non-graduates' scores deviated more from the mean than the graduates'. See Figure 1 to Figure 4 for illustration of this emerging pattern among some selected variables.

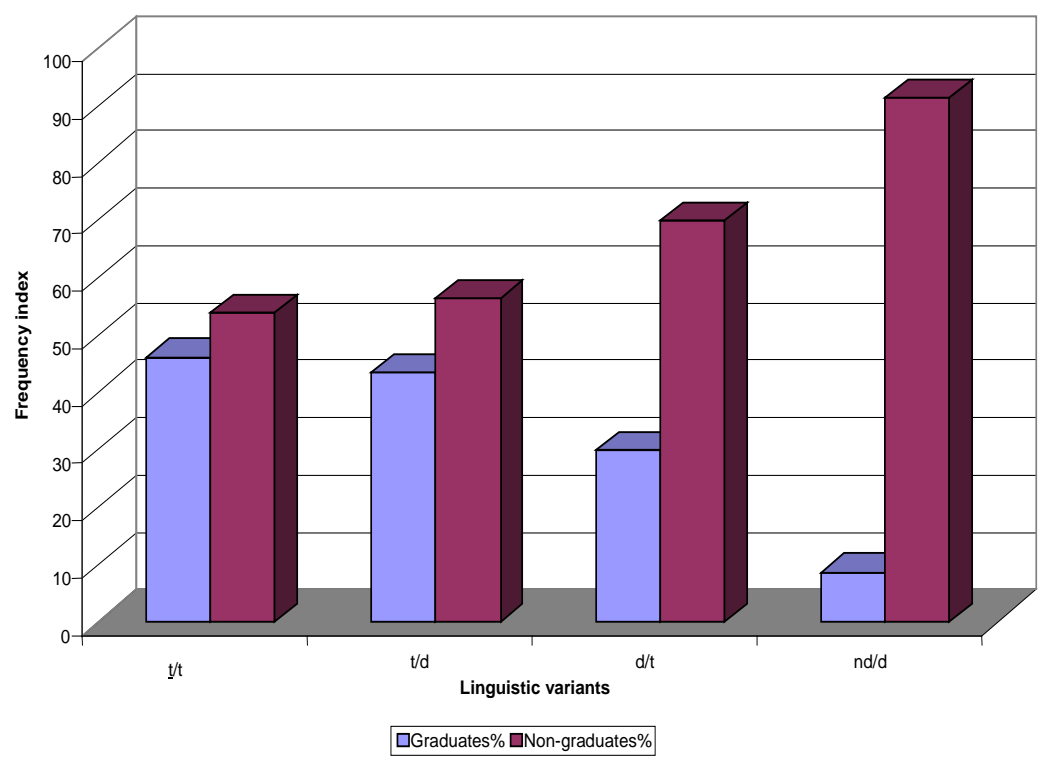

Figure 1. Education and the articulation of alveolar plosives 


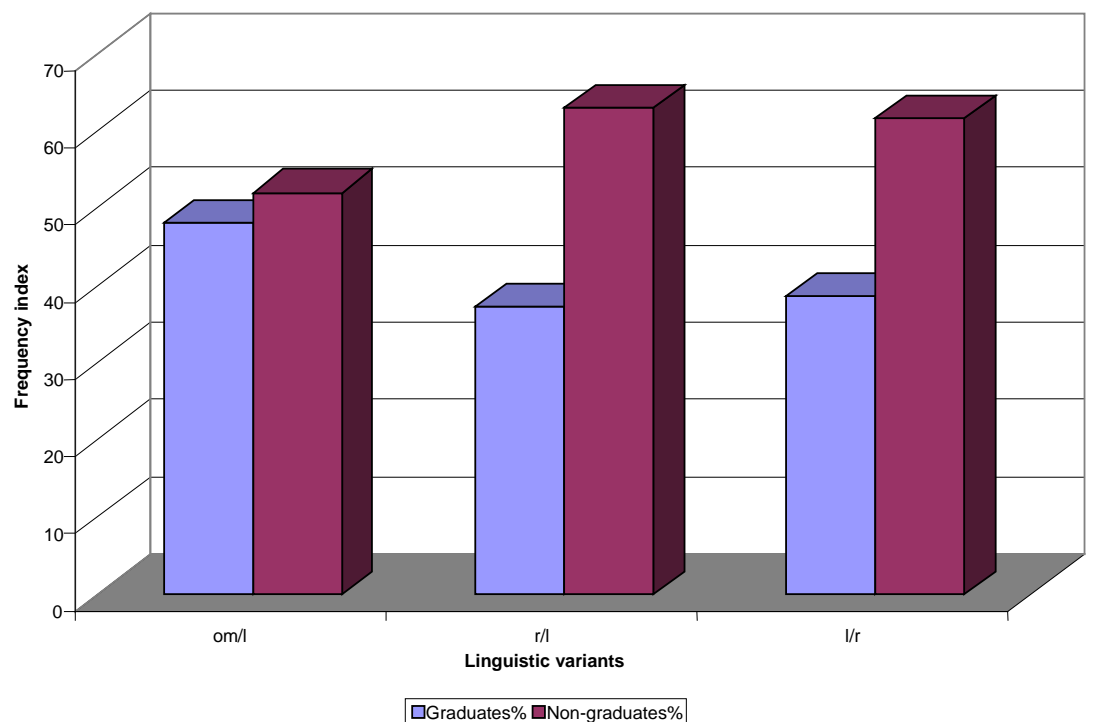

Figure 2. Education and the articulation of approximants

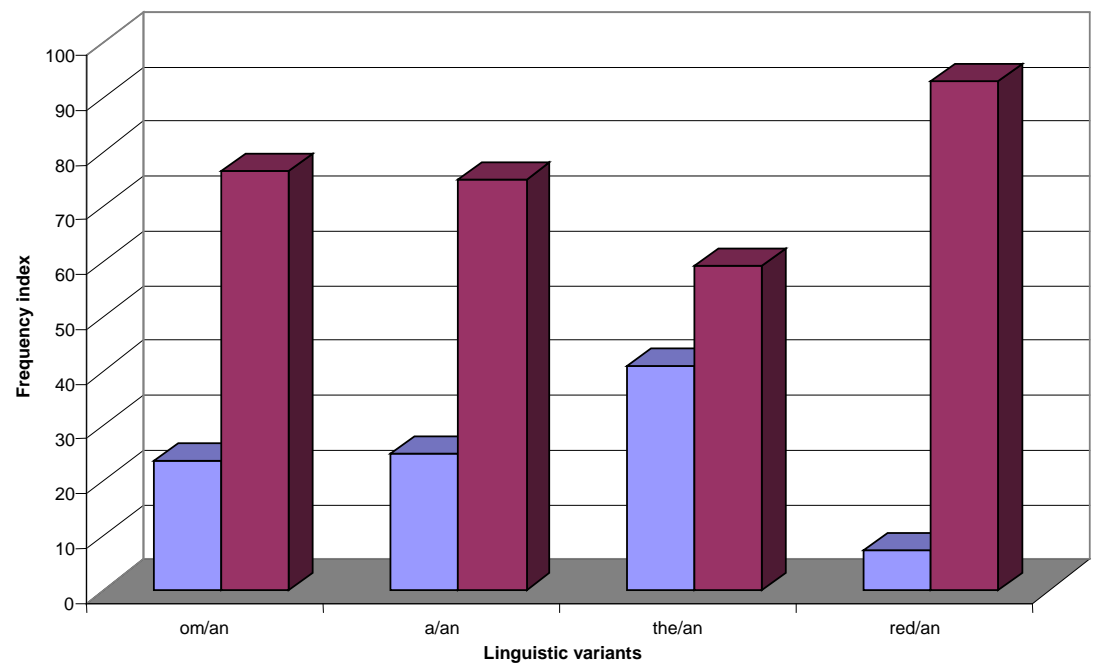

QGraduates\% $\square$ Non-graduates\%

Figure 3. Education and the use of the article (an)

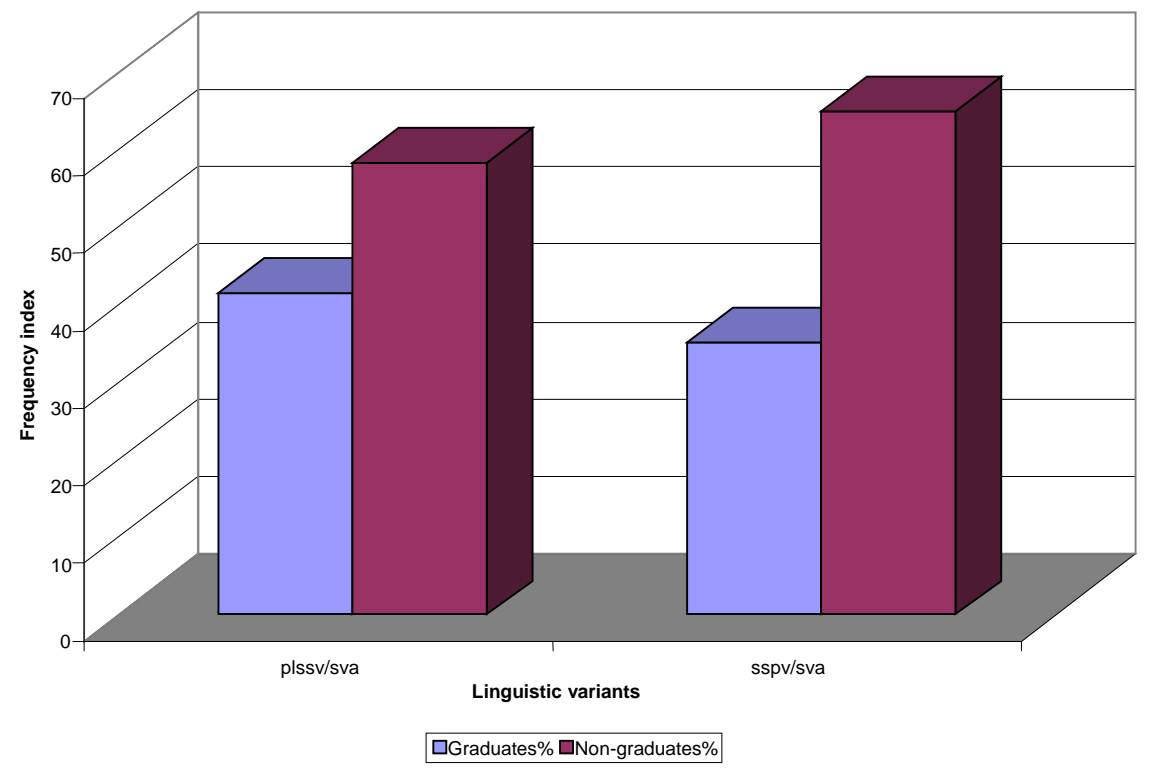

Figure 4. Education and the use of subject-verb agreement 
As illustrated by the sampled graphs, the spoken English of graduate speakers had fewer variations from the standard forms than the non-graduate speakers' and this pattern cut across all the linguistic variants. This observation supports the findings in sociolinguistics studies that, in contexts where one learns English in a formal context, the higher a person advances in the education system, the less one's language forms vary from the standard forms [18].

Table 1 - Table 5 below present the results of the ANOVA analysis for phonological and grammatical variation by education. In the interpretation of the ANOVA results, the statistical value was deemed significant at the level of $\mathrm{p}<0.05$. An asterisk $(*)$ beside a particular ANOVA value shows that it is statistically significant. Please see Table 1 and Table 2 of the Appendices for the key of linguistic variant symbols.

Table 1. ANOVA- Education and phonological variation

\begin{tabular}{|c|c|c|c|c|c|}
\hline Variant & $\begin{array}{l}\text { Sum of } \\
\text { squares }\end{array}$ & df & $\begin{array}{c}\text { Mean } \\
\text { square }\end{array}$ & $\mathrm{F}$ & Sig \\
\hline $\begin{array}{c}\mathrm{l} / \mathrm{r} \text { Between } \\
\text { groups } \\
\text { Within groups } \\
\text { Total }\end{array}$ & $\begin{array}{c}6.750 \\
328.917 \\
335.667\end{array}$ & $\begin{array}{c}1 \\
46 \\
47\end{array}$ & $\begin{array}{l}35.021 \\
35.419\end{array}$ & 0.944 & $0.0336 *$ \\
\hline $\begin{array}{c}\text { b/p Between } \\
\text { groups } \\
\text { Within groups } \\
\text { Total }\end{array}$ & $\begin{array}{c}31.688 \\
488.292 \\
519.979\end{array}$ & $\begin{array}{c}1 \\
46 \\
47\end{array}$ & $\begin{array}{l}31.688 \\
10.615\end{array}$ & 2.985 & 0.091 \\
\hline $\begin{array}{c}\text { mb/b Between } \\
\text { groups } \\
\text { Within groups } \\
\text { Total }\end{array}$ & $\begin{array}{c}12.00 \\
93.667 \\
105.667\end{array}$ & $\begin{array}{c}1 \\
46 \\
47\end{array}$ & $\begin{array}{l}12.00 \\
2.036\end{array}$ & 5.893 & $0.019 *$ \\
\hline $\begin{array}{c}\beta / \mathrm{b} \text { Between } \\
\text { groups } \\
\text { Within groups } \\
\text { Total }\end{array}$ & $\begin{array}{c}1.333 \\
25.333 \\
26.667\end{array}$ & $\begin{array}{c}1 \\
46 \\
47\end{array}$ & $\begin{array}{l}1.333 \\
0.551\end{array}$ & 2.421 & 0.127 \\
\hline $\begin{array}{l}\text { k/g Between } \\
\text { groups } \\
\text { Within groups } \\
\text { Total }\end{array}$ & $\begin{array}{c}4.083 \\
149.833 \\
153.917\end{array}$ & $\begin{array}{c}1 \\
46 \\
47\end{array}$ & $\begin{array}{l}4.083 \\
3.257\end{array}$ & 1.254 & 0.269 \\
\hline $\begin{array}{l}\text { yg/g Between } \\
\text { groups } \\
\text { Within groups } \\
\text { Total }\end{array}$ & $\begin{array}{c}4.688 \\
54.792 \\
59.479\end{array}$ & $\begin{array}{c}1 \\
46 \\
47\end{array}$ & $\begin{array}{l}4.688 \\
1.191\end{array}$ & 3.935 & 0.053 \\
\hline $\begin{array}{l}\mathrm{d} / \mathrm{t} \quad \text { Between } \\
\text { groups } \\
\text { Within groups } \\
\text { Total }\end{array}$ & $\begin{array}{c}3.000 \\
110.250 \\
113.250\end{array}$ & $\begin{array}{c}1 \\
46 \\
47\end{array}$ & $\begin{array}{l}3.000 \\
2.397\end{array}$ & 1.252 & 0.269 \\
\hline $\begin{array}{l}\text { nd/d Between } \\
\text { groups } \\
\text { Within groups } \\
\text { Total }\end{array}$ & $\begin{array}{c}7.521 \\
66.458 \\
73.979\end{array}$ & $\begin{array}{c}1 \\
46 \\
47\end{array}$ & $\begin{array}{l}7.521 \\
1.445\end{array}$ & 5.206 & $0.027 *$ \\
\hline
\end{tabular}

There is a significant statistical difference in mean scores in the use of lateral approximant [l] where [r] was expected and in the pre-nasalization of voiced plosive sounds [b] and [d], but no significant statistical difference in the mean scores is noted in the articulation of the rest of the variants. The interpretation of ANOVA, therefore, suggests that the amount of education a speaker has in English language significantly influences the phenomenon of pre-nasalization of voiced plosives and in the use of post alveolar approximant.
Table 2. ANOVA- Education and pronoun copying

\begin{tabular}{|c|c|c|c|c|c|}
\hline Variant & $\begin{array}{c}\text { Sum of } \\
\text { squares }\end{array}$ & Df & $\begin{array}{c}\text { Mean } \\
\text { square }\end{array}$ & F & Sig \\
\hline $\begin{array}{c}\text { pronc/ø Between } \\
\text { groups } \\
\text { Within groups } \\
\text { Total }\end{array}$ & 5.333 & 1 & 5.333 & 6.146 & $0.017 *$ \\
45.250 & 47 & 0.868 & & \\
\hline
\end{tabular}

There is a significant statistical difference in the mean scores recorded in the use of pronoun copying by both graduates and non-graduates with a level of significance of $p=0.017$. Thus, the level of education has a significant influence on the variation observed in the use of pronoun copying.

Table 3. ANOVA- Education and use of preposition

\begin{tabular}{|c|c|c|c|c|c|}
\hline Variant & $\begin{array}{c}\text { Sum of } \\
\text { squares }\end{array}$ & Df & $\begin{array}{c}\text { Mean } \\
\text { square }\end{array}$ & F & Sig \\
\hline om/prep & 11.021 & 1 & 11.021 & 8.599 & $0.005^{*}$ \\
Between groups \\
Within groups \\
Total & 58.958 & 46 & 1.282 & & \\
\hline subst/prep & 28.921 & 1 & 28.521 & 14.345 & $0.001^{*}$ \\
Between groups & 91.458 & 46 & 1.988 & & \\
Within groups & 119.979 & 47 & & & \\
Total & & & & & \\
\hline red/prep & 2.521 & 1 & 2.521 & 3.706 & 0.060 \\
$\begin{array}{c}\text { Between groups } \\
\text { Within groups } \\
\text { Total }\end{array}$ & 31.292 & 46 & 0.680 & & \\
\hline
\end{tabular}

There is a significant statistical difference in mean scores recorded in the variation observed in the omission of a required preposition and in substitution of prepositions. For example, the omission of an obligatory preposition and substitution of prepositions record a $\mathrm{p}=0.005$ and $\mathrm{p}=0.001$ levels of significance respectively. This suggests that the level of education of a speaker significantly affects variability in the use of preposition.

Table 4. ANOVA- Education and Subject Verb Agreement

\begin{tabular}{|c|c|c|c|c|c|}
\hline Variant & $\begin{array}{l}\text { Sum of } \\
\text { squares }\end{array}$ & Df & $\begin{array}{l}\text { Mean } \\
\text { square }\end{array}$ & $\mathrm{F}$ & Sig \\
\hline $\begin{array}{c}\text { plssv/sva } \\
\text { Between groups } \\
\text { Within groups } \\
\text { Total }\end{array}$ & $\begin{array}{c}7.521 \\
45.458 \\
52.979\end{array}$ & $\begin{array}{c}1 \\
46 \\
47\end{array}$ & $\begin{array}{l}7.521 \\
0.988\end{array}$ & 7.610 & $0.008 *$ \\
\hline $\begin{array}{c}\text { ssplv/sva } \\
\text { Between groups } \\
\text { Within groups } \\
\text { Total }\end{array}$ & $\begin{array}{l}24.083 \\
67.167 \\
91.250\end{array}$ & $\begin{array}{c}1 \\
46 \\
47\end{array}$ & $\begin{array}{c}24.083 \\
1.460\end{array}$ & 16.494 & $0.001 *$ \\
\hline
\end{tabular}

In terms of education, there is a significant statistical difference in mean scores in the use of the two variants observed in the subject-verb agreement variable. Thus, the amount of education in English language that a speaker has attained generally has a significant effect on language variability as shown in the use of subject-verb agreement in this study. 
Table 5. ANOVA- Education and use of the Article

\begin{tabular}{|c|c|c|c|c|c|}
\hline Variant & $\begin{array}{l}\text { Sum of } \\
\text { squares }\end{array}$ & Df & $\begin{array}{l}\text { Mean } \\
\text { square }\end{array}$ & $\mathrm{F}$ & Sig \\
\hline $\begin{array}{c}\text { om/a Between } \\
\text { groups } \\
\text { Within groups } \\
\text { Total }\end{array}$ & $\begin{array}{c}8.333 \\
26.667 \\
35.000\end{array}$ & $\begin{array}{c}1 \\
46 \\
47\end{array}$ & $\begin{array}{c}8.33 \\
0.580\end{array}$ & 14.375 & $0.001^{*}$ \\
\hline $\begin{array}{l}\text { the/a Between } \\
\text { groups } \\
\text { Within groups } \\
\text { Total }\end{array}$ & $\begin{array}{c}4.083 \\
29.583 \\
33.667\end{array}$ & $\begin{array}{c}1 \\
46 \\
47\end{array}$ & $\begin{array}{l}4.083 \\
0.643\end{array}$ & 6.349 & $0.015^{*}$ \\
\hline $\begin{array}{c}\text { red/a Between } \\
\text { groups } \\
\text { Within groups } \\
\text { Total }\end{array}$ & $\begin{array}{c}5.333 \\
41.333 \\
46.667\end{array}$ & $\begin{array}{c}1 \\
46 \\
47\end{array}$ & $\begin{array}{l}5.333 \\
0.899\end{array}$ & 5.935 & $0.019 *$ \\
\hline $\begin{array}{c}\text { om/an Between } \\
\text { groups } \\
\text { Within groups } \\
\text { Total }\end{array}$ & $\begin{array}{c}1.687 \\
11.292 \\
12.979\end{array}$ & $\begin{array}{c}1 \\
46 \\
47\end{array}$ & $\begin{array}{l}1.687 \\
0.245\end{array}$ & 6.875 & $0.012^{*}$ \\
\hline $\begin{array}{l}\text { a/an Between } \\
\text { groups } \\
\text { Within groups } \\
\text { Total }\end{array}$ & $\begin{array}{c}1.333 \\
13.333 \\
14.667\end{array}$ & $\begin{array}{c}1 \\
46 \\
47\end{array}$ & $\begin{array}{l}1.333 \\
0.290\end{array}$ & 4.600 & $0.037 *$ \\
\hline $\begin{array}{c}\text { red/an Between } \\
\text { groups } \\
\text { Within groups } \\
\text { Total }\end{array}$ & $\begin{array}{c}3.000 \\
12.917 \\
15.917\end{array}$ & $\begin{array}{c}1 \\
46 \\
47\end{array}$ & $\begin{array}{l}3.000 \\
0.281\end{array}$ & 10.684 & $0.002 *$ \\
\hline $\begin{array}{l}\text { om/the Between } \\
\text { groups } \\
\text { Within groups } \\
\text { Total }\end{array}$ & $\begin{array}{c}5.333 \\
26.583 \\
31.917\end{array}$ & $\begin{array}{c}1 \\
46 \\
47\end{array}$ & $\begin{array}{l}5.333 \\
0.578\end{array}$ & 9.229 & $0.004 *$ \\
\hline $\begin{array}{l}\text { a/the Between } \\
\text { groups } \\
\text { Within groups } \\
\text { Total }\end{array}$ & $\begin{array}{c}2.521 \\
19.958 \\
22.479\end{array}$ & $\begin{array}{c}1 \\
46 \\
47\end{array}$ & $\begin{array}{l}2.521 \\
0.434\end{array}$ & 5.810 & $0.020^{*}$ \\
\hline
\end{tabular}

There are significant statistical differences in mean scores in eight out of the twelve variants in the use of the article. For example, in omission of the indefinite article a, the significant value is 0.001 at $5 \%$ level of significance. Education, therefore, seems to have a significant effect on the variability observed in the use of articles in this study.

\section{Implications}

The findings reveal that the amount of education completed in the English language significantly influences linguistic variation, perhaps because in non-native contexts English is mainly learned in formal educational settings (cf. Table 1- Table 5 above). The results point out that the further a speaker advances in education, thus receiving more input in the English language, the closer his or her English will be to the standard varieties. The study thus reveals that a higher level of education contributes to a reduction of the variation from the standard forms (see Appendices). Notwithstanding, there is a discrepancy between the theoretical norm of the English language used in education (RP) and the actual language behavior in the classrooms, which needs to be addressed.
The study has implications for continuing education programs in Kenyan universities. A significant finding in this study is the importance of education in determining proficiency in a language. In other words, the spoken English of graduate teachers as speakers of English vary less from the RP than their non-graduate counterparts' does (cf. Figure 1- Figure 4 above). The graduate teacher sample in this study has been exposed to more advanced studies in English language at the university and perhaps has become more conscious of the standard pronunciation and the rules of English grammar. It is my recommendation, therefore, that more non-graduate primary school teachers be encouraged to join continuing education programs in Kenyan universities. From the literature reviewed, it emerged that the curriculum for English at primary teachers colleges covers only the basics of the English language [33]. Additional exposure to the language will enhance their proficiency in the use of English. The teachers will receive more exposure to advanced English phonology and grammar thus making their spoken English more intelligible nationally and internationally. The Kenyan government, through the Teachers Service Commission and Higher Education Loans Board (HELB), should facilitate this move by providing financial support in terms of, for example, loans to these teachers, so that financial constraints do not deter many teachers from pursuing these programs.

The results also have an implication for the trainers of teachers in Kenya. The Kenyan primary school curriculum is viewed as the foundation upon which the mastery of formal learning of skills must be laid. The main objective of teaching English in upper primary is that at the end of the primary course the learner is able to communicate fluently, independently and accurately in the language. Focus should, therefore, be on correct pronunciation, grammar and vocabulary [12]. In this regard, the skills of reading, writing and the communication skills of listening and self-expression must be taught to satisfactory levels to provide smooth transition to secondary education [19]. Despite this specific objective, Totally Integrated Quality Education and Training (TIQET), established in 1998 to investigate and recommend the way forward in terms of education in Kenya, concludes that standards of education at the primary school level have gone down. Some of the reasons attributed to the falling standards include inadequate training of teachers of English. Trainees in these colleges have to study over fourteen subjects; thus, exhaustive coverage of each subject area such as the English language is hardly achieved. Perhaps inclusion of advanced English phonetics, phonology and grammar in the primary teacher colleges' curriculum will help to address these "low standards" of English. Ultimately, the learners will be, by extension, exposed to target-like forms through their teachers' English.

\section{Conclusion}

Two significant findings have emerged in this paper. On the one hand, the English spoken by teachers in Kenyan primary schools exhibit features that appear to have been nativized, perhaps due to the sociolinguistic 
situation in which English finds itself in Kenya. English is generally learnt in schools as a third language after a child has already acquired a command of the ethnic and Kiswahili languages. The reality in Kenyan classrooms is that the teacher is the main source of input for the learner of the English language and yet these teachers, as the results indicate, are as yet to acquire a native-like control of the language. Although outside the scope of this paper, critically questioning an RP standard within Kenya's formal education is thus an important one indeed, worthy of future work.

On the other hand, education has emerged as a significant marker of language variability as revealed in this study. This implies that more exposure to advanced English phonology and syntax makes speakers with advanced training use more target-like English forms than their counterparts who have not had the opportunity of pursuing such programs. This calls for more establishments of continuing programs in Kenyan universities that will facilitate higher enrolment of primary school teachers in such courses so that they can benefit from this exposure. In the long run, the teachers' spoken English, and that of their learners, will be more mutually intelligible with other Standard English varieties to enable ease in international communication.

\section{References}

[1] Zuengler, J. (1982). Kenyan English. In B. Kachru (Ed.), The other tongue: English across cultures (pp. 112-124). Oxford: Pergamon Press.

[2] Muthwii, M. \& Kioko, A. (Eds.). (2004). New language bearings in Africa: A fresh quest. Clevedon: Multilingual Matters.

[3] Ashcroft, B., Griffiths, G., \& Tiffin, M. (1989). The empire writes back: Theory and practice in post-colonial literatures. London: Rutledge.

[4] Ellis, R. (2000). The study of second language acquisition. Oxford: Oxford University Press.

[5] Platt, J., Weber, H. \& Lian, M. (1984). Singapore and Malaysia: Varieties of English around the world. Amsterdam and Philadelphia: Benjamins.

[6] Bamgbose, A. (1995). English in the Nigerian environment. In A. Bamgbose, A. Banjo, \& A. Thomas (Eds.), New Englishes: A West African perspective (pp. 9-26). Mosuro: The British Council.

[7] Bokamba, E. (1984). The fiction of the native speaker in L2 research. In J.E. Alatis (Ed.), GURT on languages and linguistics (pp. 243- 252). Washington: Georgetown University Press.

[8] Bamgbose, A., Banjo, A. \& Thomas, A. (Eds.). (1995). New Englishes: A West African perspective. Mosuro: The British Council.

[9] Chick, J. \& Wade, R. (1997). Restandardization in the direction of a new English: Implications for access and equity. Journal of Multilingual and Multicultural Development, 18(4), 271-284.

[10] Kembo-Sure (2004). Establishing national standard and English language curriculum change in Kenya. In M.J. Muthwii \& A.N. Kioko (Eds.), New language bearings in Africa: A fresh quest (pp. 101-115). Clevedon: Multilingual Matters.

[11] Kioko, A. \& Muthwii, M. (2001). The demands of a changing society: English in education in Kenya today. Language, Culture and Curriculum, 14(3), 201-213.
[12] Kenya Institute of Education (2002). Revised English syllabus for Kenya primary schools. Nairobi: Kenya Literature Bureau.

[13] Republic of Kenya (1999). National and housing census. Nairobi: Government Printers.

[14] Mbaabu, I. (1996). Language policy in East Africa. Nairobi: ERAP.

[15] Abdulaziz, M. (1991). East Africa. In J. Cheshire (Ed.), English around the world: Sociolinguistic perspectives (pp. 391-401). Cambridge: Cambridge University Press.

[16] Kanyoro, M. (1991). The politics of English language in Kenya and Tanzania. In J. Cheshire (Ed.), English around the world: Sociolinguistic perspectives (pp. 402-419). Cambridge: Cambridge University Press.

[17] Muthiani, J. and Muchiri, M. (1987). Teaching English in Kenya secondary schools. Nairobi: Ministry of Education Publications.

[18] Schmied, J. (1991). English in Africa: An Introduction. London: Longman.

[19] Totally Integrated Quality Education and Training (1999). Totally integrated quality education and training report of the commission of inquiry into the education system of Kenya. Nairobi: Government Printers.

[20] Jones, D. (1975). An outline of English phonetics (15 ${ }^{\text {th }}$ ed.). Cambridge: Cambridge University Press.

[21] Roach, P. (1998). English phonetics and phonology ( $2^{\text {nd }}$ ed.). Cambridge: Cambridge University Press.

[22] Nthiga, P. (2003). Patterns of code switching in pre-primary classroom discourse in selected schools at Kasarani Division, Nairobi. Unpublished MA Thesis, Kenyatta University, Kenya.

[23] Nyamasyo, E. (1994). An analysis of the spelling errors in the written English of Kenyan pre- university students. Language, Culture and Curriculum, 7 (1), 79-92.

[24] Wardhaugh, R. (1998). An introduction to sociolinguistics. (2 ${ }^{\text {nd }}$ ed.). Oxford: Blackwell.

[25] Gathumbi, A. W. (1995). Verbal discourse events in a bilingual formal setting: instructional procedures in ESL classrooms in Kenyan secondary schools. Unpublished PhD Thesis, University of Reading, UK

[26] Chaudron, C. (1995). Second language classroom: Research on teaching and learning. Cambridge: Cambridge University Press.

[27] Gass, S. \& Selinker, L. (2001). Second language acquisition: An introductory course. Mahwah, NJ: Erlbaum Associates.

[28] Schneider, E. (2004). Investigating variation and change in written documents. In J. Chambers, P. Trudgill \& N. Schilling-Estes (Eds.), The handbook of language variation and change (pp. 6796). Oxford: Blackwell.

[29] Milroy, L. \& Gordon, M. (2003). Sociolinguistics: Method and interpretation. Oxford: Blackwell.

[30] Cheshire, J. (1982). Variation in English dialect: A sociolinguistic study. Cambridge: Cambridge University Press.

[31] Wells, J. C. (1982). Accents of English. Cambridge: Cambridge University Press.

[32] Quirk, R., Greenbaum, S., Leech, G. \& Svartvik, J. (1985). A comprehensive grammar of the English language. London: Longman.

[33] Kenya Institute of Education (1999). Primary teachers education pre-service programme syllabus. Nairobi: Kenya Literature Bureau.

[34] Rubdy, R. (2003). Remaking Singapore for the new age: Official ideology and the realities of practice in language-in-education. In A. Lin \& P. Martin (Eds.), Decolonisation, globalisation: Language-in-education policy and practice (pp. 55-73). Clevedon, UK: Multilingual Matters.

[35] Lemon, L. (n.d). Singapore English: Status, use and politics. Retrieved Jan 10, 2007 from www.angelfire.com/planet. 